\title{
CZECH FARMERS' EXPERIENCE WITH BT MAIZE: FULFILMENT, AND THE OPPOSITE, OF MONSANTO'S PROMISES
}

\author{
Veronika Chvátalová ${ }^{1}$ \\ ${ }^{1}$ Department of Environmental Studies, Faculty of Social Studies, Masaryk University, Žerotínovo nám. 617/9, \\ 60200 Brno, Czech Republic
}

Link to this article: https://doi.org/10.11118/actaun202068010025

Received: 15. 1. 2019, Accepted: 28. 1. 2020

To cite this article: CHVÁTALOVÁ VERONIKA. 2020. Czech Farmers' Experience with Bt Maize: Fulfilment, and the Opposite, of Monsanto's Promises. Acta Universitatis Agriculturae et Silviculturae Mendelianae Brunensis, 68(1): 25-38.

\begin{abstract}
Genetically modified (GM) Bt maize MON810 is promoted as being beneficial for farmers and the environment. The aim of this study was to compare particular claims of the benefits associated with this GM maize with Czech farmers' practice. Ten semi-structured interviews and 27 questionnaires obtained from Czech farmers who had grown Bt maize for at least one year in 2005-2016 were analysed qualitatively.

The alleged benefits of MON810 cultivation regarding lower levels of fungal disease infestation, yield increase, reduction of insecticide usage, lowered costs, time saving and simple manipulation were enjoyed by a varying proportion of Czech GM farmers. In contrast, some farmers experienced the opposite of the claimed benefit regarding yield, costs, manipulation and time requirements. The exception was the 100\% control of the European Corn Borer (ECB). The current and previous studies suggest that most of the benefits manifest themselves rather on farms under high ECB pressure. Seen from an economic viewpoint, the cultivation of Bt maize could be recommended in areas with persistent high corn borer pressure. However, the benefit to the environment is challenged and it is suggested that farmers should employ a complex of cultural control methods.
\end{abstract}

Keywords: genetically modified, Bt maize, MON810, farmers, Monsanto, benefits, European corn borer, environment, Czech Republic

\section{INTRODUCTION}

Genetically modified (GM) crops were commercialized more than 20 years ago with a promising future. Recently developed new plant breeding techniques carry on the same hopes as the "old" genetic engineering, predicting more precise breeding methods, higher yields, resistance to diseases, decreased use of pesticides, drought tolerance and improved nutritious quality (James and Krattiger, 1996; Borlaug, 2000; Cressey, 2013; Parrett, 2015; Cerier, 2018). The degree to which the advantages that were claimed came true has been reviewed with inconsistent results, see e.g.
(Benbrook, 2012; Gilbert, 2013; Apiolaza, 2014; Heinemann et al., 2014). The first generation of GM crops was designed predominantly to benefit farmers. Yet the experience of the most important stakeholders is underrepresented in the literature. The aim of this research study was to compare particular claims of the benefits associated with GM maize MON810 with Czech farmers' practice.

\section{Cultivation of $B t$ Maize in the EU}

$B t$ maize MON810 is currently the only GM crop whose cultivation is permitted in the EU. It was authorized in 1998 but first grown in 2003 in Spain, with the majority of European countries never 
joining in (Ministerio de Agricultura Alimentación y Medio Ambiente, 2012; James, 2016). On the contrary, the number of member states that have ceased the cultivation of MON810 or imposed a ban on it has been increasing since that time (Devos et al., 2014). It was grown only in Portugal and Spain in 2017, with the largest European cultivation area being in Spain (ISAAA, 2017).

In the Czech Republic, Bt maize was grown for commercial purposes from 2005 until 2016 continuously. The greatest cultivation area, in 2008, did not exceed 3\% of the total maize acreage (Křístková, 2009). The decrease recorded since then was caused by problematic sales, negligible pressure imposed by the pest to which the plant is resistant, strict co-existence rules and the fact that some companies did not deliver GM seeds to the Czech Republic (Křístková, 2009; Jordán, 2015).

This type of GM maize produces the Cry $1 \mathrm{Ab}$ protein, which is toxic for certain lepidopteran insect pests, including the European Corn Borer (ECB) (Ostrinia nubilalis) and pink borers (Sesamia spp.) (Monsanto Company, 2007).

A complex of control methods that rely, besides direct treatment, on cultural measures is advised in order to combat the ECB (Ústřední kontrolní a zkušební ústav zemědělský, 2018). The direct measures that are practised include chemical and biological control (Meissle, Romeis and Bigler, 2011). The application of relatively cheap chemical insecticides requires special and expensive machinery because of the height of maize stands (ibid.). Broad-spectrum insecticides that control several arthropod pests at once are usually used (ibid.).

Biological control consists of the air or hand application of the Trichogramma wasp spp., which parasitizes on ECB eggs (Ústřední kontrolní a zkušební ústav zemědělský, 2018). Its efficacy compares to that of chemical insecticides under optimal conditions (Meissle, Romeis and Bigler, 2011). The maize area treated with the parasitic wasp shows an increasing trend in the Czech Republic (Ústřední kontrolní a zkušební ústav zemědělský, 2018).

Another possible way to fight infestation is to plant GM maize resistant to ECB. These plants continuously produce $B t$ toxins that are active against the larvae of the pest. The control is thus independent of the weather and farmers' chances to monitor pest arrival and apply insecticides or parasitic wasps.

Bt maize MON810 is promoted as being beneficial for farmers and the environment. Some of the benefits listed by the patent holder Monsanto include: $100 \%$ control of corn borers, healthy production, increased yield, lowering the unit costs of maize production, reduction of the usage of insecticide, simplicity of manipulation and saving time (Monsanto, no date).
Research has been undertaken to evaluate the claimed benefits in the European context. The efficacy against the ECB and fungal infestation was investigated in field trials (Folcher et al., 2010; Kocourek and Stará, 2012) and commercial fields (Darvas et al., 2011; Selwet, 2011; Thieme et al., 2018). The yield was also evaluated in fields trials (Andersen et al., 2007; Schiefer et al., 2008; Křístková, 2009; Kocourek and Stará, 2012) and under commercial cultivation (Gómez-Barbero, Berbel and Rodríguez-Cerezo, 2008; Schiefer et al., 2008; Křístková, 2009). Křístková (2009) reported on the profitability of $B t$ maize cultivation that was assessed by cost-benefit analysis based on farm data, Gómez-Barbero, Berbel and Rodríguez-Cerezo (2008) and Schiefer et al. (2008) indicated gross margin difference between $B t$ and conventional maize cultivated commercially. Relevantly, a European review by Wolf and Vögeli (2009) and the data from the abovementioned studies suggest that the benefits concerning fungal diseases, yields, insecticides and costs are relative. Furthermore, apart from some indications based on the advantages and disadvantages reported by Czech $B t$ maize growers, the alleged simplicity of manipulation and saving time have not been evaluated (Křístková, 2009).

Only three European publications reported on, among other things, farmers' experience with some of the claimed benefits. Gómez-Barbero, Berbel and Rodríguez-Cerezo (2008) evaluated yield, economic performance and the use of insecticides based on data from over 400 Spanish farmers who cultivated Bt (Bt176 and MON810) and/or conventional maize in the years 2002-2004. Křístková (2009) analysed data on yield and economic performance from over 150 Czech farmers who cultivated Bt maize in the years 2005-2007. The German assessment of farms' yield draw on the experience of nine farmers who cultivated Bt maize in 2007 (Schiefer et al., 2008). Moreover, Schiefer et al. (2008) suggest that in order to evaluate the economic performance of Bt maize planting, further research should include observation in the practice, not only conducting field trials.

\section{Aim of the Current Study}

Although Bt maize MON810 has been cultivated in the EU for 17 years, there are gaps and inconsistencies in the published literature. The aim of this study was therefore to contribute to the assessment of all of the claimed benefits based on farmers' experience covering the entire period of Bt maize cultivation in the Czech Republic (20052016). The research was guided by the research question: "How do the benefits claimed by the GM maize seed producer correspond to the agricultural practice as reported by Czech GM farmers?” Only those claims of benefits that are targeted at farmers are explored. 


\section{MATERIALS AND METHODS}

\section{Technical Guide for the Cultivation of YieldGard ${ }^{\circledR}$ Corn Borer Maize}

Farmers buying Bt maize seed receive a Technical Guide for the cultivation of YieldGard ${ }^{\circledR}$ Corn Borer maize issued by Monsanto. It contains information about the plant, the pest to which it is resistant, farmers' obligations and a list of benefits introduced by the quote "What does the YieldGard® insecticide protection technology mean?" (Monsanto, undated). Seven out of ten claims concerning its benefits (presented in results and discussion in quotation marks) were chosen for the analysis as they rest on certain assumptions.

\section{Interviews}

All the Czech farmers who grew Bt maize in $2015^{1}$ $(\mathrm{N}=11)$ were invited to interviews at the beginning of February 2016. Their contact details were found by searching the Land Parcel Identification System (LPIS) using GM maize field location data which was obtained through the Free Access to Information Act No. 106/1999 Coll. Interviews with ten $^{2}$ agronomists were carried out by the author in February and March 2016, in most cases directly on their farms. The semi-structured interviews were based on an interview guide ${ }^{3}$ provided to the interviewees prior to the meetings.

The interview and questionnaire questions focused on agricultural practice, maize pests, biodiversity, co-existence, motivations to begin, continue or discontinue $B t$ maize growing, overall experience with $B t$ maize and attitudes to GM crops.

Eight interviews were audio-recorded with the agronomists' consent. The recordings were transcribed and analysed using grounded theory coding in Atlas.ti. The farmers who were interviewed are presented here under the codes F1 to F10 to ensure anonymity.

\section{Questionnaires}

A list of all the Czech growers cultivating Bt maize MON810 in 2005-2014 was obtained through the Free Access to Information Act No. 106/1999 Coll.
All the subjects whose addresses were indicated in the list and had not been interviewed in 2015 were invited to participate in the research in the second half of February 2017. ${ }^{4}$ A total of 216 agronomists were asked by email or mail to fill in an anonymous online questionnaire ${ }^{5}$ or its paper version. The response rate achieved after two reminder emails equalled 13\% ( $n=27)$. The interview and questionnaire data from questions phrased in the same way was merged for the analysis. The overall response rate thus increased to $16 \%$ (37 respondents out of 226).

The characterization of non-respondent farmers is based on the feedback provided by some agronomists who refused to return the questionnaire. Reported reasons for not filling the questionnaire were mainly that it had been a long time since the end of Bt maize cultivation (the responsible agronomist was not in charge any more or s/he did not have sufficient information to answer the detailed questions) or the fact that they only tried Bt maize on a small scale in one season and did not feel competent to answer. The only data the competent Czech authorities provide is the number of growers per year and the overall size of the commercially cultivated $B t$ maize area (see Tab. I), which does not permit comparison with the anonymous data of the respondent sample. ${ }^{6}$

The questionnaire provided data from farmers growing Bt maize in the period 2005-2014. The farmers who were interviewed reported on the year 2015, including the only agronomist who continued to grow Bt maize in 2016. The total sample thus covers the entire period for which $B t$ maize was grown in the Czech Republic from 2005 to 2016.

\section{Sample Characteristics}

Each farm with identification details that had grown $B t$ maize for at least one year since the beginning of its cultivation in the Czech Republic was invited to participate in the research. Different durations of cultivation (1-10 years) and each year of cultivation (2005-2016) are covered. The participants had the opportunity to skip questions and to reply "I do not know" to the majority of the

1 The Bt maize acreage accounted only for 0.3\% of the total maize acreage in the Czech Republic in 2015 (Jordán, 2015)

2 The contact details of farmer F10 were obtained later, so that he was contacted at the beginning of the season and refused to have a personal interview for time reasons. Only a short telephone interview was conducted. Additional information was adopted from interviews he provided to the magazines Farmář (Hruška, 2012) and Euro (Weikert, 2014).

3 The interview guide is available as the Supplementary file 1.

4226 out of 233 subjects with address details were eligible for the research. The seven excluded subjects were: four subjects that ceased to exist in the course of the years, two school farms and one research institute.

5 The questionnaire is available as the Supplementary file 2.

6 Surprisingly, some farmers responded that they did not cultivate GM maize. This might be explained by the fact that any subject growing $B t$ maize must notify this to the competent Czech authority, regardless of the scale of cultivation. Agronomists usually try new crop varieties in small field trials, which was reportedly the case of some GM maize growers. They might therefore not have been aware of Bt maize cultivation on their farm (especially if it was many years ago). 
I: Size of the MON810 cultivated area and the number of its growers in the Czech Republic

\begin{tabular}{lcc}
\hline Year & $\begin{array}{c}\text { Size of the commercially } \\
\text { cultivated MON810 area } \\
\text { in the CR (Ha) }\end{array}$ & $\begin{array}{c}\text { Number of } \\
\text { MON810 growers }\end{array}$ \\
\hline 2005 & 270 & 51 \\
\hline 2006 & 1290 & 82 \\
\hline 2007 & 5000 & 126 \\
\hline 2008 & 8380 & 167 \\
\hline 2009 & 6480 & 121 \\
\hline 2010 & 4680 & 82 \\
\hline 2011 & 5090 & 64 \\
\hline 2012 & 3050 & 41 \\
\hline 2013 & 2560 & 31 \\
\hline 2014 & 1754 & 18 \\
\hline 2015 & 997 & 11 \\
\hline 2016 & 75 & 1 \\
\hline 2017 & 0 & 0 \\
\hline 2018 & 0 & 0 \\
\hline 2019 & 0 & 0 \\
\hline $5019:$ & & \\
\hline
\end{tabular}

Source: Ministry of Agriculture

questions. The number of valid answers (other than "I do not know") thus varies between 28 and 37 for the respective benefits, and between 21 and 36 for the respective farm and farmer characteristics. The small size of the sample did not permit statistical analysis. Therefore, only the percentage and a proportion of particular answers out of the total valid answers to a particular question are indicated.

The farmers ${ }^{7}$ were between 31 and 65 years old ( $n=33$, median 49). Eighty-eight percent (29 out of 33) of them were in the function of an agronomist on the farm when $B t$ maize was first cultivated there. The highest level of education achieved by $67 \%$ (23 out of 34) of the farmers was a university degree, 9\% (three out of 34) of them had attended a higher professional school and 24\% (eight out of 34) of them had passed the 'matura' (school-leaving) exam.
Ninety-two percent (33 out of 36) of the farms operated both plant and animal production, while 8\% (three out of 36) focused only on plant production. Other characteristics are presented in Tab. II.

\section{RESULTS}

\section{" $100 \%$ Control of European Corn Borer During the Whole Period of Cultivation"}

The farmers who were interviewed characterized $B t$ maize plants as pretty, healthy and not broken, thanks to which they are not infested with fungal diseases. Although two agronomists noticed "bite marks" in Bt maize plants, they emphasized that this variety was more resistant to the ECB than the conventional one. Similarly, F5 described Bt maize as not being infested at all or only minimally. Despite the traces of this pest activity in Bt maize fields, all the farmers who were interviewed concurred that $B t$ maize provides efficient protection against the ECB.

Eighty-five percent (28 out of 33) of the farmers reported a difference in the rate of ECB infestation between $B t$ and conventional maize. The farmers did not comment on the nature of the difference but since no one complained about the susceptibility of GM maize to this pest, I interpret this as meaning that $B t$ maize was better protected compared to the conventional type.

The answers of $76 \%$ (26 out of 34) of the Czech farmers indicate that they complied with the refuge requirements, i.e. non-Bt maize was planted on minimally $20 \%$ of the $B t$ maize acreage. Where its form was described, the refuge was always sown as a buffer crop (a means to ensure the co-existence of $B t$ and non-Bt maize). Nearby conventional maize fields belonging to the particular GM maize farmers were also often considered a refuge.

\section{"Healthy Production Thanks to Lower Infestation with Fungal Diseases"}

Sixty-one percent (17 out of 28) of the farmers reported the same rate of infestation with plant diseases in Bt and conventional maize. No extra

II: Farm characteristics

\begin{tabular}{lcccc}
\hline & $\begin{array}{c}\text { Farm's area of arable } \\
\text { land (Ha) }\end{array}$ & $\begin{array}{c}\text { Percentage of owned arable land } \\
\text { out of total arable land }\end{array}$ & $\begin{array}{c}\text { Annual turnover } \\
\text { (millions of CZK) }\end{array}$ & $\begin{array}{c}\text { Number of } \\
\text { employees }\end{array}$ \\
\hline Minimum & 60 & 5 & 4 & 3 \\
Maximum & 6500 & 66 & 286 & 150 \\
Median & 1629 & 24 & 20 & 21 \\
Valid answers & 36 & 23 & 33 \\
\hline
\end{tabular}

7 The terms "farmer" and "agronomist" are used as synonyms throughout the text as only farmers in the position of agronomists and owners of family farms were surveyed. 
observation was recorded in these cases and so it was assumed that both types of plants were diseasefree. Prior to $B t$ maize cultivation the ECB was a significant pest on $41 \%$ (seven out of 17) of these farms. A difference in the infestation rate reported by $39 \%$ (11 out of 28 ) of the respondents was interpreted as less infection in $B t$ maize compared to conventional maize (again, no extra observation was reported). The corn borer was a significant pest on the majority of these farms (91\%, 10 out of 11).

\section{"Yield Increase Thanks to Intact and Healthy Plants"}

The farmers were asked if they had recorded differences in the yield amount between $B t$ and conventional maize under comparable conditions (FAO, hybrid, acreage, soil) in the same seasons. ${ }^{8}$ Bt maize was compared to untreated conventional maize on $64 \%$ (21 out of 33) of the farms and to insecticidally treated conventional maize on $36 \%$ (12 out of 33) of the farms.

The same yields for both maize types were indicated by $55 \%$ (18 out of 33 ) of the farmers. Bt maize was compared to untreated conventional maize in 78\% (14 out of 18) of the cases. The ECB had been a significant pest on 67\% (12 out of 18) of these farms in the past.

Thirty percent (10 out of 33) of the farmers recorded higher yields of $B t$ maize compared to the conventional type (compared to untreated maize in $60 \%$, six out of 10 cases). The ECB was a significant pest on $60 \%$ (six out of 10) of these farms. The yield increase averaged 12\% (a range of 5-40\%); however, this figure is rough because it is based on six cases in which the respondents provided more details.

Fifteen percent (five out of 33) of the agronomists reported lower $B t$ maize yields compared to conventional maize (compared to untreated maize in $20 \%$, one out of five cases). The ECB represented a significant pest on 60\% (three out of five) of the farms. The difference in yield indicated in two cases ranged from -5 to $-15 \%$.

The farmers who were interviewed gave possible explanations for the lower yield of the $B t$ maize. According to F9, lower yields reflect Bt maize's overall worse quality caused by a lack of innovation in GM varieties compared to conventional varieties (which can make better use of nutrition and water). Farmer F4 stated that the yield losses of Bt maize observed in some seasons were caused by wild boars. The agronomist explained that boars feed on maize ears which are available sooner or in fields closer to a forest, which was the case of his Bt maize plants. This experience contrasts with two other farmers, who stated that boars prefer conventional maize fields. The reasons, in F8's opinion, are the earlier maturity of conventional maize, its better availability because of the shorter plants, or a substance produced by $O$. nubilalis that is attractive for boars.

Some of the farmers who were interviewed said that the yield is dependent on climatic conditions and pest infestation. Bt maize reportedly gives higher yields only in a normal season (average precipitation) and when conventional fields are infested with the ECB, under an unfavourable climate (heat, drought), the yield is the same.

\section{"Reduction of Insecticide Usage and Hence a Significant Relief for the Environment"}

The farmers were asked if they used insecticides against the ECB before, during and after the Bt maize cultivation period and if the amount of insecticides applied per hectare of maize changed.

Insecticides were used against the European corn borer on 51\% (19 out of 37) of the farms before Bt maize was adopted. Although the ECB was considered a significant pest prior to $B t$ maize cultivation on $68 \%$ (25 out of 37 ) of the farms $36 \%$ of these farmers did not treat it with insecticides (nine out of 25).

The number of farms using ECB insecticides decreased while Bt maize was being cultivated, compared to the times before and after its cultivation (Fig. 1). Fifty-three percent (10 out of 19) of the farmers who used to spray these pesticides prior to GM farming kept on doing so on conventional maize fields, while 47\% (nine out of 19) abandoned the chemical treatment of conventional maize when they adopted Bt maize.

The amount of insecticides used per hectare of maize decreased with the adoption of $B t$ maize on $42 \%$ (15 out of 36 ) of the farms. The ECB was a significant pest prior to the adoption of $B t$ maize on $87 \%$ (13 out of 15) of these farms. Fifty-eight percent (21 out of 36) of the farmers did not record any change in the amount of insecticides applied. The ECB was only a significant pest on 52\% (11 of 21) of these farms.

\section{"Technology Securing the Profitability of Maize Cultivation Through Lowering the Unit Costs of Maize Production"}

The farmers were asked how the unit costs of maize production changed after the introduction

8 The farmers who were interviewed were asked to provide actual figures for $B t$ and conventional maize grain and silage yields. Since some of them did not have actual numbers and only provided estimates, the questionnaire was simplified in such a way that they could choose from options of the same/higher/lower/don't know Bt maize yield compared to the conventional type. The estimation of the percentage difference between the two yields was encouraged. 


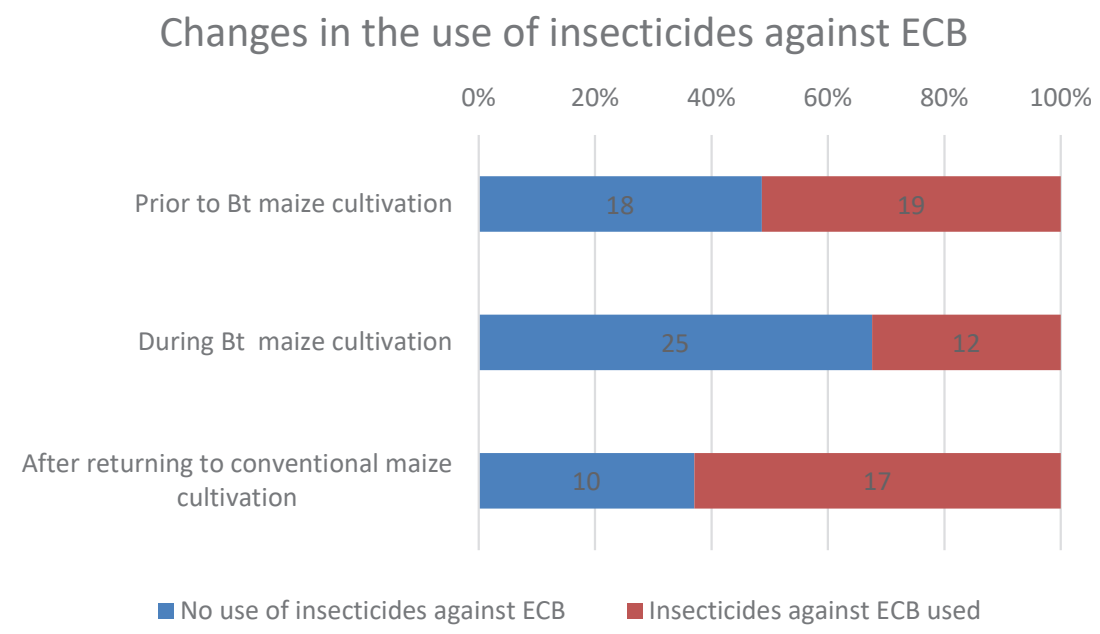

1: Changes in the use of insectircides against the European corn borer. The numbers in columns indicate the numbers of farmers

of $B t$ maize cultivation. ${ }^{9}$ Forty-three percent (13 out of 30) reported no changes, 33\% (10 out of 30) indicated higher costs and 23\% (seven out of 30) of the agronomists recorded lower unit costs of maize production.

The same costs were experienced by the farmers irrespective of yields (the same or a higher or lower Bt maize yield was reported by $54 \%, 31 \%, 15 \%$ of these farmers, respectively) and independently of insecticide usage. Insecticides against the ECB were applied by $46 \%$ (six out of 13) of these farmers and the amount of insecticides remained unchanged after the adoption of $B t$ maize in $46 \%$ (six out of 13) of the cases or decreased in 54\% (seven out of 13) of the cases. The farmers who were interviewed reported the same costs before and after the introduction of $B t$ maize explained that the higher yields of $B t$ maize were balanced out by the higher prices for purchasing its seed. The corn borer was a significant pest before $B t$ maize was adopted on $54 \%$ (seven out of 13 ) of the farms.

The unit costs of maize production increased on farms with the same (80\%, eight out of 10) or lower (20\%, two out of 10) Bt maize yields. An insecticide against the ECB was only used on 10\% (one out of 10) of the farms and the amount of insecticides used decreased on other $10 \%$ (one out of 10) of the farms. The corn borer was a significant pest before $B t$ maize was adopted on $60 \%$ (six out of 10) of the farms.

Farmers whose costs of maize production unit decreased declared that they had the same $(60 \%$, three out of five) or higher (40\%, two out of five) $B t$ maize yields (two did not know the difference in yield). Twenty-nine percent (two out of seven) of these farmers used insecticides and the amount of insecticides remained the same in $43 \%$ (three out of seven) of the cases or decreased in 57\% (four out of seven) of the cases compared to the times before the cultivation of $B t$ maize. The corn borer was a significant pest before $B t$ maize was adopted on $71 \%$ (five out of seven) of the farms with lowered costs.

\section{"Simple Manipulation" and "Time Saving, No Need for Signalling of Pest Arrival"10}

Thirty-nine percent (13 out of 33) of the farmers experienced time saving. Ninety-two percent (12 out of 13) of them used to apply insecticides against ECB to maize before $B t$ maize was adopted and 69\% (nine out of 13) of them also continued spraying conventional maize while cultivating $B t$ maize. Furthermore, ECB was a significant pest before the adoption of $B t$ maize on $85 \%$ (11 out of 13) of these farms.

The same time requirements before and during Bt maize cultivation were reported by 39\% (13 out of 33) of farmers. Ninety-two percent (12 out of 13) and 100\% (13 out of 13) of them did not apply insecticides before and during $B t$ maize cultivation, respectively. The ECB was a significant pest on $62 \%$ (eight out of 13) of these farms.

Increased time requirements after adopting Bt maize was indicated by $21 \%$ (seven out of 33 ) of the farmers. They did not change their practice of insecticide application with their adoption of Bt maize. Only 29\% (two out of seven) stopped the application, whereas 14\% (one out of seven) continued the application and 57\% (four out of seven) sprayed neither before nor during $B t$ maize

9 The respondents could choose from the options of the same/higher/lower/don't know unit costs of maize production compared to the period before the adoption of Bt maize.

10 Farmers' experience shows that the two claims about manipulation and working time go hand in hand; therefore, they will be addressed together. 
cultivation. The ECB was considered a significant pest on 29\% (two out of seven) of these farms before $B t$ maize cultivation was initiated. The farmers with this experience who were interviewed mentioned reasons such as organizing sowing, paperwork, keeping records and farm inspections.

Another feature of time and manipulation that was quantified was the number of entries into Bt maize cover compared to conventional maize. Forty-seven percent (17 out of 36) of respondents reported fewer entries into Bt maize fields. Thirtyfive percent (six out of 17) of these farmers entered $B t$ maize fields fewer times, although they did not apply insecticides against the ECB in conventional fields. Fifty-three percent (19 out of 36) of the respondents did not record any change in the number of entries. Almost no one (5\%, one out of 19) used insecticide in conventional maize fields.

\section{DISCUSSION}

The MON810 maize belongs among those GM crops designed to bring benefits to growers. The agronomic characteristics and performance were tested before the product was introduced onto the market. Yet the alleged benefits manifest themselves to various degrees during commercialscale cultivation (Křístková, 2009; Wolf and Vögeli, 2009). Moreover, the level of the benefits that are claimed tends to be overestimated. A survey among European farmers with no experience with the cultivation of GM crops showed that the expected rate of increase in sale prices and yields is much larger than the real increases recorded in Spain (Tillie, Dillen and Rodríguez-Cerezo, 2016).

\section{“100\% Control of European Corn Borer During the Whole Period of Cultivation”}

The efficacy of the $B t$ maize reported by the farmers agrees with other Czech and European evidence. MON810 showed 100\% efficacy in the reduction of the number of tunnels caused by the ECB in field trials in the Czech Republic (Kocourek and Stará, 2012). The Czech Central Institute for Supervising and Testing in Agriculture monitored the biological efficacy of commercially grown Bt maize between 2006 and 2015. Their results did not indicate the development of ECB-resistant populations as no infested Bt plants, or only a few, were identified (Křístková, 2009; Lvončík, 2010; Radová, 2011, 2012, 2013, 2014; Ústřední kontrolní a zkušební ústav zemědělský, 2015, 2016).

As the Bt toxin kills the larvae upon ingestion, they need to feed on the plant tissue and short tunnels may thus be observed. Isolated findings of caterpillars' activity may also be explained by their immediate identification after they got to the Bt maize from another host plant (Křístková, 2009). Other studies also reported a negligible extent of damaged stalks and ears of Bt maize plants in field trials in Europe and the USA (events MON810,
Bt176 and stacks including MON810) but overall highly effective control of the ECB (Magg et al., 2001; Mihalčík et al., 2012; Bohnenblust et al., 2014).

Moreover, no field-evolved resistance has been documented for the ECB in Europe or North America (Thieme et al., 2018). However, resistance to MON810 maize was reported for a Lepidopteran pest in South Africa as a result of a low refuge compliance, among other factors (ibid.). European farmers cultivating $B t$ maize are required to sow non-Bt maize in part of the fields to form a refuge where the ECB could feed without developing resistance. Three-quarters of the Czech farmers who were sampled indicate that they complied with the refuge requirements. In comparison, Spanish farmers increased their refuge compliance from an initial 58\% in 2004 to around 90\% in recent years (EFSA et al., 2018).

In conclusion, the Czech GM maize farmers confirmed the highly effective control of the European corn borer reported from field trials and the monitoring of commercial fields in the Czech Republic and Europe.

\section{"Healthy Production Thanks to Lower Infestation with Fungal Diseases”}

Once blighted by the European corn borer, maize plants are easily susceptible to secondary infestation with fungal diseases (Nedělník, Lindušková and Kmoch, 2012). Fungi produce mycotoxins that may be dangerous for human and animal health (ibid.). The protection against ECB should then assist in assuring a healthy production.

Less infection in Bt maize compared to conventional maize was reported by $39 \%$ of the farmers in the current survey. The corn borer was a significant pest on the majority of these farms. In comparison, according to a previous survey of Czech GM maize farmers, two-thirds of them recorded lower levels of fungal infestation (Křístková, 2009). No difference was reported from farms with very low or no corn borer infestation or from farms with a high ECB pressure where insecticides were applied (ibid.).

Lower levels of infection with the Fusarium genus and mycotoxin levels in $B t$ maize hybrids compared to their conventional counterparts were also recorded in field trials in the Czech Republic (Slezáková, 2005; Slezáková et al., 2006; Kocourek and Stará, 2012). Kmoch et al. (2011), on the other hand, did not identify any significant difference in the intensity of Fusarium infection between the two varieties and mixed results were reported by Nedělník, Lindušková and Kmoch (2012). $B t$ maize was infected less, more or the same as the conventional variety, depending on the particular species of Fusarium (Nedělník, Lindušková and Kmoch, 2012). European field research also showed lower levels of Fusarioses and mycotoxins in MON810 maize compared to conventional varieties, although the efficacy of $B t$ maize differed for various mycotoxins (Folcher et al., 2010; Darvas et al., 2011; Selwet, 2011). 
In conclusion, thanks to its resistance to the European corn borer Bt maize usually provides protection against some fungal diseases. On the evidence of this and a previous survey of Czech GM farmers, this effect seems to be more pronounced on farms where the ECB causes significant damage. It can save additional costs on these farms related to the removal of mycotoxins from feed and the negative impact on the health and productivity of farm animals (Kř́stková, 2009).

\section{"Yield Increase Thanks to Intact and Healthy Plants”}

The European corn borer is currently the most important arthropod pest of maize, occurring in 20$60 \%$ of European fields (Meissle et al., 2010). Yield losses range from 5 to 30\% in areas highly infested with the ECB where no control measures are applied (ibid.). The occurrence of the ECB and the damage caused by it have been increasing in the Czech Republic, with estimated 10-20\% yield losses in grain maize (Kocourek and Stará, 2012). Bt maize should secure higher yields thanks to its protection against damage by the European corn borer.

The majority (55\%) of the farmers who were surveyed reported the same yields. Only 30\% indicated higher Bt maize yields and $15 \%$ of the agronomists recorded lower $B t$ maize yields. Previous studies in the Czech Republic documented higher Bt maize MON810 yields both in commercial cultivation and trials (Křístková, 2009; Kocourek and Stará, 2012). Although a minority of Czech farmers recorded lower Bt maize yields, over $60 \%$ experienced an average $8 \%$ yield increase in the seasons from 2005 to 2007 (Křístková, 2009).

Field trials in other European countries also showed MON810 yields to be higher (Bereś, 2010; Mihalčík et al., 2012). However, mixed results were reported from trials and commercial cultivation, ranging from a lower $B t$ maize yield through no difference to higher Bt maize yields (Andersen et al., 2007; Gómez-Barbero, Berbel and RodríguezCerezo, 2008; Wolf and Vögeli, 2009).

The farmers who were interviewed found the yield to be dependent on climatic conditions and pest infestation. Their observations agree with studies reporting that the yield increase depends highly on the climatic conditions of the growing season (Kocourek and Stará, 2012) and on ECB pressure (Křístková, 2009; Wolf and Vögeli, 2009; Mihalčík et al., 2012). Bt maize MON810 provided a small increase in yields or almost none at all in years with low corn borer infestation and 15-25\% increase under high pest pressure in Czech variety trials (Kř́stková, 2009). Contrary to that, Schiefer et al. (2008) reported no difference in yield between MON810 and non-Bt hybrids in trials despite greater damage caused by the ECB to untreated conventional maize. Nevertheless, German farmers recorded higher MON810 yields compared to conventional maize despite low levels of ECB damage to conventional maize (ibid.).

In conclusion, the differences between $B t$ and conventional maize yields appear to be highly variable and dependent on many conditions. The "yield increase thanks to intact and healthy plants" is usually manifested when the occurrence of the ECB is high. Yet it also depends on the pressure from other pests (e.g. damage by boars) and climate. In seasons with no or low European corn borer infestation $B t$ maize provides similar yields or sometimes even lower ones than conventional varieties.

\section{"Reduction of Insecticide Usage and Hence a Significant Relief for the Environment"}

Monsanto argues that growing Bt maize reduces insecticide usage and thus brings about significant relief for the environment. This assumes that insecticides used to be applied against the ECB before the adoption of $B t$ maize and that the amount used decreased on farms where $B t$ maize was employed; and that $B t$ maize is toxic only for the pest.

The argument of insecticide usage reduction is not very convincing in the sample of Czech GM maize farmers. Half of them did not apply insecticides against the ECB before adopting Bt maize anyway. Of those who did, only $47 \%$ abandoned this praxis during the time they were cultivating $B t$ maize. Additionally, the amount of insecticides used decreased on $42 \%$ of the farms.

These results are comparable to other available Czech data. Although the European corn borer occurs in all the maize grain production areas in the Czech Republic, only half of this area was treated with ECB insecticides in 2008 and less than a quarter of the total maize acreage in 2009 (Křístková, 2009; Kocourek and Stará, 2012). Insecticides were applied to less than $20 \%$ of the maize areas monitored in 2016 and 2017 (Ústřední kontrolní a zkušební ústav zemědělský, 2017, 2018).

Hungarian farmers do not use insecticides against the ECB as the yield losses tend to be small (Darvas et al., 2011). Only 14\% of Greek farmers used insecticides against the ECB although it was considered an important pest (Skevas et al., 2012). The European exception is Spain, where 58\% of conventional maize was sprayed with insecticides against the ECB in 2002-2004 (Gómez-Barbero, Berbel and Rodríguez-Cerezo, 2008). This compares to the extent of insecticides applied to maize in general reviewed by Meissle et al. (2010). Zero to $11 \%$ of the maize crop area was treated in Italy, France, the Netherlands and Denmark, and 20-50\% in Germany, Poland, Hungary and Spain (ibid.).

Another question is whether the use of insecticides can be reduced in the long term, as the need to apply them can arise with secondary pest outbreaks (Meissle, Romeis and Bigler, 2011; Catarino et al., 2016). On the basis of a model Catarino et al. (2016) predicted that if no additional 
measures are taken, the damage caused to crops by secondary pests can increase with the expansion of Cry1Ab Bt maize cultivation in Europe.

Moreover, it is generally assumed that the replacement of chemical insecticides with plantbased toxins is beneficial for the environment as their mode of action is believed to be specific for certain species pest (Meissle, Romeis and Bigler, 2011). However, according to a review by Hilbeck and Otto (2015), an increasing body of evidence suggests a significant cross-order activity of Cry toxins. The class of Cry1 proteins (to which the MON810-maize-produced Cry1Ab toxin belongs) has been reported to be toxic against nonlepidopteran non-target organisms (Latham, Love and Hilbeck, 2017). Moreover, significant activity of MON810 maize itself against caddis flies, water fleas and earthworms has been documented (Hilbeck and Otto, 2015; Latham, Love and Hilbeck, 2017). Latham, Love and Hilbeck (2017, p. 87) therefore argue that GM crop-produced toxins "deserve much greater attention and may be of equal or greater concern than conventional pesticides".

In conclusion, the present results show in agreement with European data that the reduction of insecticide usage is only partial. Additionally, if the application of insecticides decreased rapidly, a secondary pest outbreak could increase the need for chemical treatment. Moreover, the toxins produced by $B t$ maize may not necessarily be less harmful to beneficial organisms than insecticides. The claim of "significant relief for the environment" as a result of the cultivation of $B t$ maize therefore seems ambiguous, especially in the long term.

\section{"Technology Securing the Profitability of Maize Cultivation Through Lowering the Unit Costs of Maize Production"}

The profitability of $B t$ maize cultivation depends on the seed price, market price of the harvest ${ }^{11}$, yield and pest control costs (Gómez-Barbero, Berbel and Rodríguez-Cerezo, 2008). Bt maize seeds are about $30 \%$ more expensive than conventional maize seeds because of a royalty fee (Křístková, 2009; Wolf and Vögeli, 2009). As described above, differences in yields and insecticide usage vary considerably.

Only $23 \%$ of the farmers who were surveyed recorded lower unit costs of maize production. The decreased costs were experienced by farmers with at least the same $B t$ and non- $B t$ maize yields and the same or a decreased amount of insecticides used, which outweighed the greater cost of the $B t$ maize seed. Increased costs reported by a third of the respondents were incurred on farms where the higher price of $B t$ maize seed was not balanced by higher yields and where the money spent on insecticides was not saved. The same costs were experienced by $43 \%$ irrespective of yields and insecticide usage.

The results compare to the higher profitability of Czech commercial Bt compared to conventional maize grain cultivation reported in 2007 (Křístková, 2009). That season was characterized by higher $B t$ maize yields and savings on the application of chemical insecticides (ibid.). Bt maize showed higher economic efficacy compared to insecticidally treated or Trichogramma controlled conventional maize also in Czech field trials (Kocourek and Stará, 2012).

A Spanish study reported that farmers growing Bt maize (MON810 and Bt176) obtained a higher gross margin than conventional maize farmers for three consecutive years (Gómez-Barbero, Berbel and Rodríguez-Cerezo, 2008). However, the benefit ranged widely, depending on the region, from 3 to 135 Euro/ha (ibid.). According to Schiefer et al. (2008) and Wolf and Vögeli (2009), increased returns can be achieved when ECB infestation is severe to very severe (compared to low and moderate) and the increased yield exceeds the cost of $B t$ maize seed.

In conclusion, as documented by the experience of the current sample of farmers and by Europewide literature, a higher yield exceeding the price of the expensive seeds and a significant corn borer infestation condition the profitability of $B t$ maize cultivation. On the basis of its economic performance, the adoption of $B t$ maize could thus only be recommended in areas with persistent high corn borer pressure. In agreement with Bohnenblust et al. (2014), these results suggest that for farmers to maximize profits, they should choose hybrids that are well adapted to the local conditions.

\section{"Simple Manipulation" and "Time Saving, No Need for Signalling of Pest Arrival"}

Monsanto promises farmers simple manipulation of Bt maize and time savings as they need not monitor the arrival of the pest. In practice, however, these benefits could be hindered as Bt maize cultivation implies holding to certain rules of coexistence and insect-resistant management. Czech GM farmers are obliged to inform their neighbours and the state authorities, keep isolation distances, label the product and keep a record (Trnková et al., 2017). Furthermore, non-Bt maize must be planted on at least $20 \%$ of the $B t$ maize acreage if the latter exceeds 5 Ha (Monsanto Europe, 2010).

On the basis of the current results, the cultivation of $B t$ maize has the potential to save time (39\% of the respondents), but only for farmers who used to apply insecticides to maize before and during $B t$ maize cultivation and rather in cases where the corn

11 Only 11\% (four out of 36) of the farmers in the current sample sold Bt maize. In a previous survey farmers expressed having experienced problems with selling it (Křístková, 2009). 
borer was a significant pest before the adoption of $B t$ maize. On the other hand, Bt maize cultivation can even increase the time requirements (21\% of the respondents), as evidenced by those farmers who did not change their insecticide usage practice and who did not consider the ECB a significant pest on their farm. Approximately half of the sample (47\%) reported fewer entries into Bt maize fields.

These findings compare to the previous survey among Czech farmers. Czech GM growers reported simple protection, the elimination of mechanization, easy harvesting and fewer entries into the maize cover as the most frequent advantages of Bt maize cultivation (Křístková, 2009). The most frequent disadvantages identified previously, consisting of the administrative burden, keeping records and farm inspections, were also complained about in the current sample (Kř́stková, 2009). In comparison, other European GM farmers consider these co- existence measures as the least burdensome (Tillie, Dillen and Rodríguez-Cerezo, 2016). Less frequent disadvantages identified previously agreed with those reported by the farmers in the current sample: more labour-intensive sowing, harvesting, manipulation and drying, and more complicated organization of sowing (Kř́stková, 2009).

To conclude, the higher demand for farm operations, work organization and administration entailed by co-existence and the insect resistance management rules impact on the claimed benefits. The extra time costs decrease with an increasing Bt maize acreage (Schiefer et al., 2008). The results suggest that $B t$ maize cultivation can save time and ease the manipulation for farmers who would have to apply insecticides and on farms with significant corn borer infestation. However, on other farms the time requirements did not change or even increased.

\section{III: Comparison of Monsanto's benefit claims with Czech GM farmers' experience and results reported in European literature}

\begin{tabular}{|c|c|c|}
\hline Monsanto's benefit claim & Czech GM farmers' experience ${ }^{\mathrm{A}}$ & European literature $^{B}$ \\
\hline $\begin{array}{l}\text { "Healthy production thanks to lower } \\
\text { infestation with fungal diseases" }\end{array}$ & $\begin{array}{l}\text { Difference in disease infestation } \\
\text { (39\% of the farmers). No infested } \\
\text { Bt maize plants. } \\
\text { Conventional plants also disease-free } \\
\text { ( } 61 \% \text { of farmers). Difference } \\
\text { on ECB-infested farms. }\end{array}$ & $\begin{array}{l}\text { Bt maize infected less, the same } \\
\text { or more as conventional maize. }\end{array}$ \\
\hline $\begin{array}{l}\text { "Yield increase thanks to intact } \\
\text { and healthy plants" }\end{array}$ & $\begin{array}{l}\text { Yield increased (30\%), the same (55\%) } \\
\text { or decreased (15\% of the farmers). }\end{array}$ & $\begin{array}{l}\text { Difference variable. Yield increased } \\
\text { (usually under high ECB pressure). } \\
\text { Yield the same when no or low } \\
\text { ECB pressure. Yield also decreased. } \\
\text { Influence of climatic conditions. }\end{array}$ \\
\hline $\begin{array}{l}\text { "Technology securing profitability } \\
\text { of maize cultivation through lowering } \\
\text { unit costs of maize production" }\end{array}$ & $\begin{array}{l}\text { Costs decreased ( } 23 \%) \text {, the same } \\
(43 \%) \text { or increased ( } 33 \% \text { of } \\
\text { the farmers). Influence of seed price, } \\
\text { yield and insecticide usage. }\end{array}$ & $\begin{array}{l}\text { Improvement in profitability varies. } \\
\text { Profitability conditioned by higher } \\
\text { yield exceeding the expensive seeds, } \\
\text { and by high ECB pressure. }\end{array}$ \\
\hline
\end{tabular}

A. Difference refers to the difference between $B t$ maize and conventional maize

B. Synthesis drawn from literature cited in the Discussion section. Studies report results from trials and commercial cultivation in European countries.

Row in green: Claim corresponds to farmers' practice.

Row in orange: Claim or its opposite manifested, or no difference, depends (inter alia) on ECB pressure.

Row in blue: Claim corresponds partly. 


\section{Conclusion Regarding Monsanto's Benefit Claims}

The experience of the surveyed Czech farmers who used to grow Bt maize confirms the alleged benefits only partly. The only claim fully corresponding to farmers' practice regards the resistance of $B t$ maize to the European corn borer. The lower fungal disease infestation of $B t$ plants was more pronounced on ECB infested-farms where conventional maize was infected. On the other hand, the claim of a reduction in the usage of insecticide was not very convincing in the current sample. Only half of the farmers used to apply insecticides against the ECB before their adoption of $B t$ maize. Of these, half stopped it when they started to cultivate Bt maize. Furthermore, the amount of insecticides used decreased on $42 \%$ of the farms.

More importantly, even the opposite of the claimed benefit manifested itself in a certain proportion of the sample for the rest of the claims. Bt maize yields were higher, the same or lower compared to conventional maize. The unit costs of maize production decreased, remained the same or increased after the adoption of Bt maize. The costs were influenced by seed price, yield and insecticide usage. Handling was made easier and time saved where farmers would have to apply insecticides and under high ECB pressure. However, the time requirements remained the same or even increased on other farms. Manipulation and working time were affected by co-existence and insect resistance management rules.

\section{CONCLUSION}

The alleged benefits of MON810 cultivation regarding lower levels of fungal disease infestation, yield increase, reduction of insecticide usage, lowered costs, time saving and simple manipulation were enjoyed by a varying proportion of Czech GM farmers who were surveyed. In contrast, some agronomists experienced the opposite of the claimed benefit regarding yield, costs, manipulation and time requirements. The exception was the $100 \%$ control of the ECB. Although a quarter of the farmers did not comply with the refuge requirements, all the farmers reported highly effective control of the pest.

The relatively small size of the current sample allowed only a qualitative assessment. The findings, however, compare to experience reported in other Czech and European studies. The current and previous studies suggest that most of the benefits manifest themselves rather on farms under high ECB pressure. As the published evidence of farmers' experience with the cultivation of GM crops in the EU is largely underrepresented, this area deserves further research, presumably in Spain and Portugal, the only remaining member states where $B t$ maize is cultivated.

The $B t$ maize MON810 is promoted as being beneficial for farmers and the environment. Seen from an economic viewpoint, the cultivation of Bt maize can be recommended in areas with persistent high corn borer pressure. Concerning the environmental effects, farmers' experience shows, however, that the reduction in the use of insecticides is only partial. Moreover, an increasing body of evidence draws attention to the negative effects of $B t$ plant-produced toxins on non-target organisms (Latham, Love and Hilbeck, 2017). The benefit to the environment is thus challenged.

In the light of the above, and because of the increasing pressure of Diabrotica virgifera (another pest to which this Bt maize is not resistant), it is recommended in accordance with the Central Institute for Supervising and Testing in Agriculture (Ústřední kontrolní a zkušební ústav zemědělský, 2018) that farmers should employ a complex of cultural control methods.

\section{Acknowledgements}

I would like to express my appreciation to all the farmers who enabled this study to emerge by sharing their experience. My thanks also go to Lubica Lacinová, Zbyněk Ulčák and Ivana Vlachová for consulting the interview guide and providing helpful comments on an earlier version of the manuscript.

This paper was written at Masaryk University as part of the project "Current environmental challenges: ways to overcome dissension between nature and society" [MUNI/A/0957/2017] with the support of the Specific University Research Grant, as provided by the Ministry of Education, Youth and Sports of the Czech Republic in the year 2018.

\section{REFERENCES}

ANDERSEN, M. N. et al. 2007. Agricultural studies of GM maize and the field experimental infrastructure of ECOGEN'. Pedobiologia, 51(3): 175-184.

APIOLAZA, L. A. 2014. Comment on sustainability and innovation in staple crop production in the US Midwest. International Journal of Agricultural Sustainability, 12(4): 383-386. 
BENBROOK, C. M. 2012. Impacts of genetically engineered crops on pesticide use in the U.S. - the first sixteen years. Environmental Sciences Europe, 24: 24.

BEREŚ, P. K. 2010. Harmfulness of Ostrinia Nublialis Hbn. on some Non-Bt Versus Genetically Modified Bt Maize (Zea Mays L.) Cultivars in Poland in 2006-2007. Journal of Plant Protection Research, 50(1): 110-116.

BOHNENBLUST, E. W. et al. 2014. Current European corn borer, Ostrinia nubilalis, injury levels in the northeastern United States and the value of Bt field corn. Pest Management Science, 70: 1711-1719.

BORLAUG, N. E. 2000. Ending World Hunger. The Promise of Biotechnology and the Threat of Antiscience Zealotry. Plant Physiology, 124(2): 487-490.

CATARINO, R. et al. 2016. Managing maize under pest species competition: Is Bt (Bacillus thuringiensis) maize the solution? Ecosphere, 7(6): e01340.

CERIER, S. E. 2018. Genetic engineering, CRISPR and food: What the 'revolution' will bring in the near future, Genetic Literacy Project. Available at: https://geneticliteracyproject.org/2018/01/24/geneticengineering-crispr-food-revolution-will-bring-near-future/ [Accessed: 2019, January 10].

CRESSEY, D. 2013. A new breed. The next wave of genetically modified crops is making its way to market - and might just ease concerns over "Frankenfoods". Nature, 497: 27-29.

DARVAS, B. et al. 2011. Relationships of Helicoverpa armigera, Ostrinia nubilalis and Fusarium verticillioides on MON 810 Maize. Insects, 2(1): 1-11.

DEVOS, Y. et al. 2014. EFSA's scientific activities and achievements on the risk assessment of genetically modified organisms (GMOs) during its first decade of existence: Looking back and ahead. Transgenic Research, 23(1): 1-25.

EFSA et al. 2018. Statement on annual post-market environmental monitoring report on the cultivation of genetically modified maize MON 810 in 2016. EFSA Journal, 16(5): e05287.

FOLCHER, L. et al. 2010. Lower mycotoxin levels in Bt maize grain'. Agronomy for Sustainable Development, 30: 711-719.

GILBERT, N. 2013. A Hard Look on GM crops. Nature, 497: 24-26.

GÓMEZ-BARBERO, M., BERBEL, J. and RODRÍGUEZ-CEREZO, E. 2008. Adoption and performance of the first GM crop introduced in EU agriculture: Bt maize in Spain. JRC Scientific and Technical Reports. Luxembourg: Office for Official Publications of the European Communities.

HEINEMANN, J. A. et al. 2014. Sustainability and innovation in staple crop production in the US Midwest', International Journal of Agricultural Sustainability, 12(1): 71-88.

HILBECK, A. and OTTO, M. 2015. Specificity and Combinatorial Effects of Bacillus Thuringiensis Cry Toxins in the Context of GMO Environmental Risk Assessment. Frontiers in Environmental Science, 3: 71.

HRUŠKA, J. 2012. Cílevědomá práce přináší výsledky. Agris. [Online]. Available at: http://www.agris. cz/zemedelstvi/cilevedoma-prace-prinasi-vysledky?id_a=177974 [Accessed: 2019, January 10].

ISAAA. 2017. Global Status of Commercialized Biotech/GM Crops in 2017: Biotech Crop Adoption Surges as Economic Benefits Accumulate in 22 Years. ISAAA Brief 53. Ithaca, NY: ISAAA.

JAMES, C. 2016. Global Status of Commercialized Biotech/GM Crops: 2016. ISAAA Brief 52. Ithaca, NY: ISAAA.

JAMES, C. and KRATTIGER, A. F. 1996. Global review of the field testing and commercialization of transgenic plants, 1986 to 1995: The First Decade of Crop Biotechnology. ISAAA Brief 1. Ithaca, NY: ISAAA.

JORDÁN, H. 2015. Geneticky modifikované kukuřice se v České republice vypěstovalo téměř o polovinu méně než v předchozím roce. eAGRI. [Online]. Available at: http://eagri.cz/public/web/ mze/tiskovy-servis/tiskove-zpravy/x2015_geneticky-modifikovane-kukurice-se-v.html [Accessed: 2019, January 10].

KMOCH, M. et al. 2011. Vliv hybridu na infekci obilek kukuřice (Zea mays L.) houbami rodu Fusarium. Úroda, 12: 217-220.

KOCOUREK, F. and STARÁ, J. 2012. Efficacy of Bt Maize against European Corn Borer in Central Europe. Plant Protection Science, 48: 25-35.

KŘÍSTKOVÁ, M. 2009. Dosavadní zkušenosti s pěstováním geneticky modifikované Bt kukuřice v ČR 2005-2009. Praha: Ministerstvo zemědělství.

LATHAM, J. R., LOVE, M. and HILBECK, A. 2017. The distinct properties of natural and GM cry insecticidal proteins. Biotechnology and Genetic Engineering Reviews, 33(1): 62-96.

LVONČíK, S. 2010. Závěrečná zpráva: Výsledky monitoringu účinnosti Bt - kukuřice v roce 2009 prováděného Státní rostlinolékařskou správou. Praha: Státní rostlinolékařská správa.

MAGG, T. et al. 2001. Comparison of Bt maize hybrids with their non-transgenic counterparts and commercial varieties for resistance to European corn borer and for agronomic traits. Plant Breeding, 120(5): 397-403. 
MEISSLE, M. et al. 2010. Pests, pesticide use and alternative options in European maize production: Current status and future prospects. Journal of Applied Entomology, 134(5): 357-375.

MEISSLE, M., ROMEIS, J. and BIGLER, F. 2011. Bt maize and integrated pest management - a European perspective. Pest Management Science, 67(9): 1049-1058.

MIHALČ́́K, P. et al. 2012. Effect of MON 810 Cultivation and Prevention to Adventitious Presence in Non-GM Fields: A Case Study in Slovakia. Plant Protection Science, 48: 11-17.

MINISTERIO DE AGRICULTURA ALIMENTACIÓN Y MEDIO AMBIENTE. 2012. El cultivo de maíz modificado genéticamente en España, Consejo Interministerial de OMG. Ministerio de Agricultura Alimentación y Medio Ambiente.

MONSANTO. Technický průvodce pro pěstování YieldGard ${ }^{\circledR}$ Corn Borer kukuřice. Monsanto ČR.

MONSANTO COMPANY. 2007. Application for renewal of the authorisation for continued marketing of existing MON 810 maize products that were authorized under Directive 90/220/EEC (Decision 98/294/ EC) and subsequently notified in accordance to Article 20 (1)(a) of Regulation (EC) No. Monstanto.

MONSANTO EUROPE. 2010. Annual monitoring report on the cultivation of MON 810 in 2009. Czech Republic, Germany, Portugal, Slovakia, Poland, Romania and Spain. Brussels, Belgium: Monstanto.

NEDĚLNÍK, J., LINDUŠKOVÁ, H. and KMOCH, M. 2012. Influence of Growing Bt maize on Fusarium Infection and Mycotoxins Content - a Review. Plant Protection Science, 48: 18-24.

PARRETT, T. 2015. GMO Scientists Could Save the World From Hunger, If We Let Them. Newsweek. Available at: https://www.newsweek.com/2015/05/29/gmo-scientists-could-save-world-hunger-ifwe-let-them-334119.html [Accessed: 2019, January 10].

RADOVÁ, Š. 2011.Závěrečná zpráva: Výsledky monitoringu účinnosti Bt. kukuřice v roce 2010 prováděného Státní rostlinolékařskou správou. Brno: Státní rostlinolékařská správa.

RADOVÁ, Š. 2012.Závěrečná zpráva: Výsledky monitoringu účinnostiBt. kukuřice v roce 2011 prováděného Státní rostlinolékařskou správou. Brno: Státní rostlinolékařská správa.

RADOVÁ, Š. 2013.Závěrečná zpráva: Výsledky monitoringu účinnostiBt. kukuřice v roce 2012 prováděného Státní rostlinolékařskou správou. Brno: Státní rostlinolékařská správa.

RADOVÁ, Š. 2014. Závěrečná zpráva: Výsledky monitoringu účinnostiBt. kukuřice v roce 2013 prováděného Ústředním kontrolním a zkušebním ústavem zemědělským. Brno: Státní rostlinolékařská správa.

SCHIEFER, C. et al. 2008. Untersuchungen zum Anbau von GVO in Sachsen. Dresden, Germany: Sächsische Landesanstalt für Landwirtschaft.

SELWET, M. 2011. Maize plants infestation by Fusarium spp. and deoxynivalenol in genetically modified corn hybrid and traditional maize cultivars. Polish Journal of Microbiology, 60(4): 317-321.

SKEVAS, T. et al. 2012. Do European union farmers reject genetically modified maize? Farmer preferences for genetically modified maize in Greece. AgBioForum, 15(3): 242-256.

SLEZÁKOVÁ, L. et al. 2006. Toxigenic micromycetes and their mycotoxins in grains of transgenic Btmaize hybrid and non-transgenic hybrids. In: ROMEIS, J. and MEISSLE, M. (Eds.). Proceedings of the meeting Ecological Impact of Genetically Modified Organisms. Lleida, Spain, pp. 159-164.

SLEZÁKOVÁ, L. et al. 2005. Toxigenic micromycetes and their mycotoxins in grains of transgenic Btmaize hybrid and non-transgenic hybrids. In: RYANT, P. et al. (Eds.). MendelNet '05 Agro - sborník abstraktů z konference posluchačů postgraduálního doktorského studia. Brno: Mendelova zemědělská a lesnická univerzita v Brně.

THIEME, T. G. M. et al. 2018. Ten years of MON 810 resistance monitoring of field populations of Ostrinia nubilalis in Europe. Journal of Applied Entomology, 142(1-2): 192-200.

TILLIE, P., DILLEN, K. and RODRÍGUEZ-CEREZO, E. 2016. Perception of Coexistence Measures by Farmers in Five European Union Member States. EuroChoices, 15(1): 17-23.

TRNKOVÁ, J. et al. 2017. Organisation and inspection of GM crops cultivation in the Czech Republic. Prague, Czech Republic: The Ministry of Agriculture of the Czech Republic.

ÚSTŘEDNÍ KONTROLNÍ A ZKUŠEBNÍ ÚSTAV ZEMĚDĚLSKÝ. 2015. Závěrečná zpráva: Výsledky monitoringu účinnosti Bt kukuřice v roce 2014 prováděného Ústředním kontrolním a zkušebním ústavem zemědělským. Brno: Ústřední kontrolní a zkušební ústav zemědělský.

ÚSTŘEDNÍ KONTROLNÍ A ZKUŠEBNÍ ÚSTAV ZEMĚDĚLSKÝ. 2016. Závěrečná zpráva: Výsledky monitoringu účinnosti Bt. kukuřice v roce 2015 prováděného ÚKZÚZ. Brno: Ústřední kontrolní a zkušební ústav zemědělský.

ÚSTŘEDNÍ KONTROLNÍ A ZKUŠEBNÍ ÚSTAV ZEMĚDĚLSKÝ. 2017. Monitoring výskytu zavíječe kukuřičného a původce bělorůžové hniloby obilek kukuřice v roce 2016. Brno: Ústřední kontrolní a zkušební ústav zemědělský.

ÚSTŘEDNÍ KONTROLNÍ A ZKUŠEBNÍ ÚSTAV ZEMĚDĚLSKÝ. 2018. Monitoring výskytu zavíječe kukuřičného a původce bělorüžové hniloby obilek kukuřice v roce 2017. Brno: Ústř̀ední kontrolní a zkušební ústav zemědělský. 
WEIKERT, P. 2014. Česko, genetický rekordman. Euro. [Online]. Available at: https://www.euro.cz/ archiv/cesko-geneticky-rekordman-1105190 [Accessed: 2019, January 10].

WOLF, D. and VÖGELI, G. A. 2009. Ökonomischer Nutzen von Bt-Mais ist relativ. Agrarforschung, 16(1): 4-9. 